\title{
Gender Difference: Students' Mathematical Literacy in Problem Solving
}

\author{
Alse Ona Sabat ${ }^{1, *}$ Mardiyana $^{2}$ Ikrar Pramudya ${ }^{3}$ \\ ${ }^{1}$ Postgraduate of Mathematics Education, Faculty of Teacher Training and Education, Universitas Sebelas \\ Maret Surakarta, Indonesia \\ ${ }^{2}$ Faculty of Teacher Training and Education, Universitas Sebelas Maret Surakarta, Indonesia \\ ${ }^{3}$ Faculty of Teacher Training and Education, Universitas Sebelas Maret Surakarta, Indonesia \\ *Corresponding author. Email: alseonasabat@student.uns.ac.id
}

\begin{abstract}
Having a good mathematical literacy is expected to help the students in learning. Mathematical literacy is an individual's ability to understand the role of mathematics and to interpret it in his everyday life. Mathematical literacy focuses on thinking mathematically, mathematical arguments, mathematical modelling, open problems and solving problems, representation, and communication. This study aims to describe the ability of students' mathematical literacy viewed from the gender difference. Type of research this is research is qualitative descriptive. The subject of this study were two female students and the two male students. Instruments used in this study is an ability test of mathematical literacy and interview. Data were analyzed with the descriptive qualitative analysis namely the data reduction, data modelling, and conclusion drawing. Male students' mathematical literacy skill was signified by the indicators on mathematical thinking, mathematical arguments, representation and communication. While female students' mathematical literacy skill was signified by the indicators on mathematical thinking, mathematical arguments, open problem and solving problems, and representation and communication. Except for mathematical modelling indicator female students possess adequate mathematical literacy skill.
\end{abstract}

Keywords: Gender, Mathematical literacy, Problem solving.

\section{INTRODUCTION}

Today's digital era has entered the realm of education [1]. Trends International Mathematics and Science (TIMMS) and Programs for International Students (PISA) become measures achievements of the students' mathematics ability in Indonesia. In 2011, TIMSS presented the average of students' achievement in Indonesia that is 386 , which means low [1]. The results of PISA in 2015 showed that students in Indonesia were on the rank 69 of the 76 countries with an average score of 386 . The results of the TIMSS in 2011 and PISA in 2015 showed that the students in Indonesia possess low mathematical literacy skill [2]. Mathematical literacy is very important to help an individual to solve the problems in his real life [3]. Mathematical literacy is the capacity of individual to identify and understand the role of mathematics in the world to make the interpretation according to his current and present needs of his private, work, and social life and to be a constructive, concerned and reflective citizen of a country [4]. Mathematical literacy is a knowledge to understand and apply basic math in everyday life [5]-[6]. Mathematical literacy consists of several indicators which can describe individual's ability to solve problem [6].

Mathematical literacy is defined as the ability to use the knowledge and understand mathematics in facing challenges [7]-[8]. On the other hand, literacy in the context of mathematics is having the power to use mathematical thinking in solving every day's problems [9]. Mathematical literacy is an individual's ability to recognize and understand the role of mathematics in real life, to provide right judge and consideration, to use mathematics for meeting his needs in a constructive society [7]. This means mathematical literacy is used to emphasize of mathematics in everyday life. Mathematical literacy is 
not limited to performing a number of procedures, and having a knowledge of the basic mathematics. In line with the opinion that was stated by the [9] who stated that the mathematical literacy includes eight competencies that must be owned. However in this study, the researchers only used 6 competencies namely: 1) mathematical reasoning and thinking: knowing types of answers for offered problems; distinguishing between the various types of problems; 2) mathematical argument: creating and expressing mathematical arguments; 3) mathematical communication: understanding the work of others; 4) modelling: changing reality into the mathematical structure; interpreting mathematical models in context or reality; 5) proposing and solving problems: formulating, defining, and solving problems in a variety ways; 6) representation and communication: distinguishing and interpreting various forms of object representation and the mathematical situation as well as understanding the relationship between different representation. Previous studies reported that the ability of mathematical literacy is influenced by biological and psychological, environmental, economy, schools, and society factors [10], as well as personal, and instructional factors [11]. The indicators of mathematical literacy are presented in Table 1. mathematical problems. The subjects of this research are 18 students from 63 students of SMP Negeri 20 Surakarta. However, this article only presented data from 4 subjects consisting of 2 male and 2 female students. The subjects were selected to obtain expected valid data. The instruments used were tests and interviews. These tests were used to determine students' ability to solve mathematical literacy problems. Interviews were conducted to know more things from the subject in interpreting their understanding of mathematical literacy. This instrument was validated by 2 lecturers with master's degrees. The validators provided suggestions that the questions can be used with a few revisions.

In qualitative research, the essential data collection techniques are tests and interviews [17]. This method aims to determine students' ability to solve mathematical literacy problems. The interview method was carried out from knowing things more deeply than the subject in interpreting their understanding of mathematical literacy. In this study, descriptive qualitative data analysis technique was used with the following stages: 1) Data reduction, namely the data obtained is quite large, for that, it needs to be recorded carefully and in detail [18]; 2) Data model can be done in the form of brief

Table 1. Mathematical literacy indicators

\begin{tabular}{l|l|}
\hline Mathematical Literacy Indicators & \multicolumn{1}{|c|}{ Definition } \\
\hline Mathematical thinking & Knowing the types of answers according to the given questions. \\
\hline Mathematical argument & Making mathematical arguments. \\
\hline Mathematical model & Interpreting mathematics in real life. \\
\hline $\begin{array}{l}\text { Open problems and problem } \\
\text { solving }\end{array}$ & $\begin{array}{l}\text { Posing, formulating, and solving various types of mathematical } \\
\text { problems. }\end{array}$ \\
\hline $\begin{array}{l}\text { Representation and } \\
\text { communication }\end{array}$ & Interpreting and finding various ways of solving problems. \\
\hline
\end{tabular}

This study aims to describe the ability of students' mathematical literacy viewed from the gender difference. It is important to conduct this study because it can improve the problem-solving, the mathematical connection, mathematical literacy, and high level of critical thinking skills [12].

\section{RESEARCH METHOD}

It is a qualitative study [13], since it produces descriptive data in the form of written or spoken words from people and observable behavior [14]. The data is presented according to the facts in the field without any manipulation [15]-[16]. This study was designed to determine students' mathematical literacy in solving descriptions, charts, relationships between categories, flowcharts and so on; 3) Drawing/Verifying Conclusions.

\section{RESULTS AND DISCUSSION}

Data obtain of this research were mathematical literacy problem in data presentation content presented in Figure 1.

Below is presented the results of the students' mathematical literacy skills viewed from gender difference and the discussion of findings in research this. The subjects were 4 consisting of 2 male and 2 


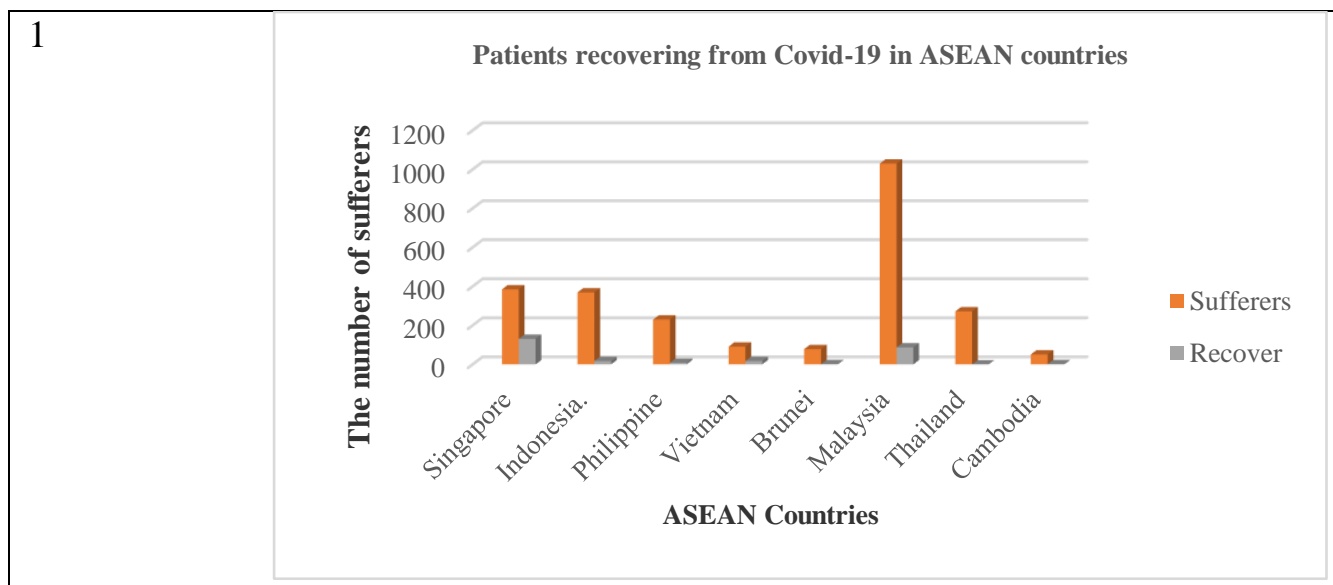

Look at the picture, then answer the following questions.

a. Since January 2020, a type of virus has caused a stir in China's Wuhan Province. Then it spreads in ASEAN countries. The ratio of recovered patients to the Covid-19 outbreak is different from one another. The country with the lowest recovery rate is...

b. Since January 2020, Covid-19 has caused a commotion in the Wuhan Province of China and has spread to ASEAN countries. Is it correct to draw the number of COVID-19 sufferers in ASEAN countries using the average concentration measure? Describe!

2 Look at the following picture!

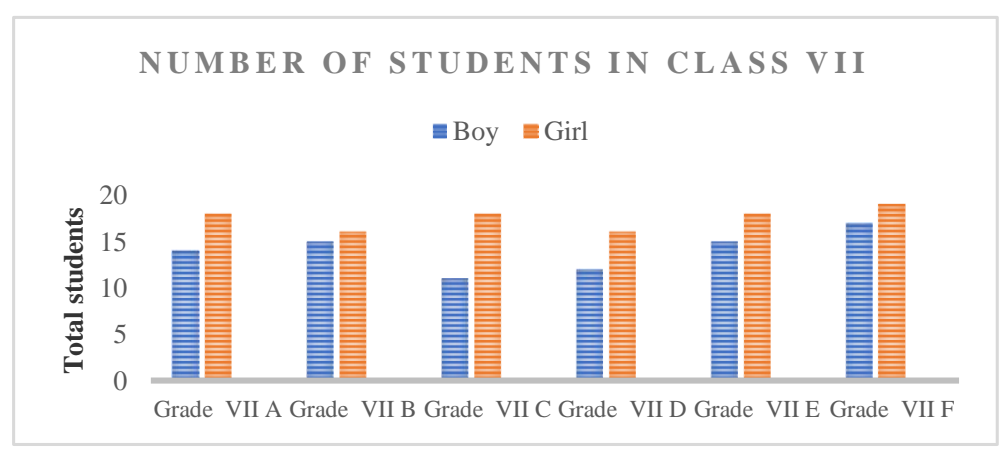

Determine the number of male students and the number of female students!

Figure 1 Mathematical literacy problem

female subjects. As for the S-1 and S-2 were males and the $\mathrm{S}-3$ and $\mathrm{S}-4$ were females. The data is presented as Figure 2.

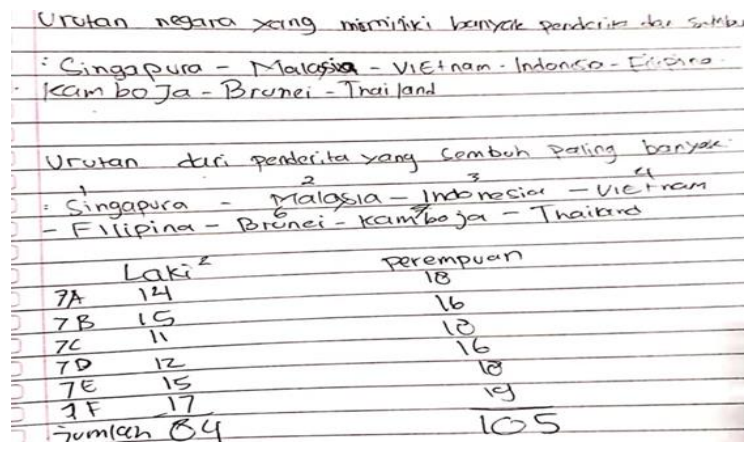

Figure 2 S-1 data
The S-1 wrote down the answers to numbers 1a and $1 \mathrm{~b}$ by sorting ASEAN countries. It can be seen that S-1 has not understood the given question. This shows that he found it difficult to interpret the information obtained from the questions presented, which causes incorrect answers. In writing the answers, S-1 did not understand the information well so he repeated the same mistakes in the second question. In question number 2, S-1 wrote down the number of male and female students correctly. By looking at the S-1's answer to the question, it can be concluded that the mistakes he made originated from being unable to understand the questions given, being unable to interpret questions in real life which caused errors in solving the mathematical problems presented. 

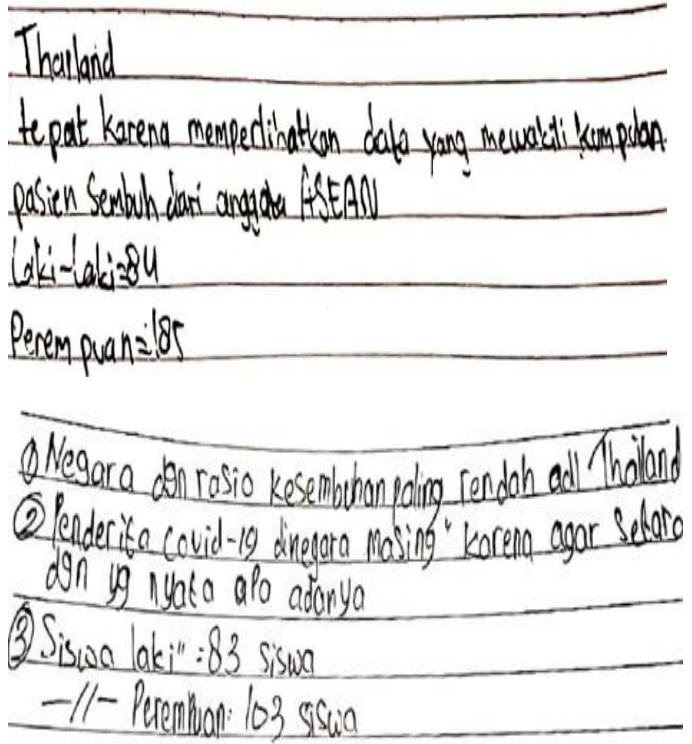

Figure 3 S-2 data

Based on Figure 3 S-2 wrote down the answer for number 1a correctly but did not describe his answer. S-2 should answer by paying attention to the existing diagram to describe the lowest recovery rate. It is suspected that S-2 has difficulty in interpreting reallife questions and formulating mathematical problems with mathematical models. For question number $1 \mathrm{~b}, \mathrm{~S}$ 2 answered that it was appropriate to draw a lot of Covid-19 sufferers by using the size of the data concentration for the wrong reasons. S-2 should give appropriate answers to the questions given by paying attention to the ratio on the diagram. In question number 2, S-2 still miscalculated the number of male and female students. It can be seen that S-2 found it difficult and was incautious to interpret open problems in the form of diagrams. Therefore, based on the problems found in questions number $1 \mathrm{a}, 1 \mathrm{~b}$, and 2 , it can be concluded that S-2 experienced difficulty in representing and communicating a mathematical problem in the form of diagrams and pictures.

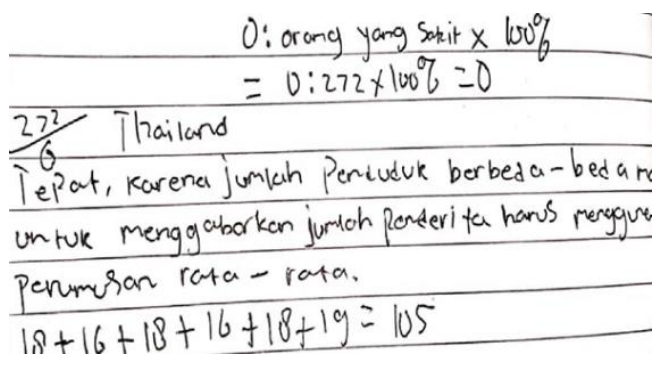

Figure 4 S-3 data

Based on Figure 4 S-3 wrote down the answer to number 1a by mentioning that Thailand is a country that has the lowest recovery rate. S-3 answered correctly. In question number $1 \mathrm{~b}, \mathrm{~S}-3$ wrote "it is appropriate" by giving a reason that the number of residents is different, however she did not pay attention to the presentation of the average concentration so, she drew an inaccurate conclusion. It is suspected that S-3 experienced difficulty in making mathematical arguments. S-3 should pay attention to the questions given to be able to answer the questions. In question number $2, \mathrm{~S}-3$ wrote down the number of female students correctly but did not write down the number of male students according to the illustration on the diagram. S-3 experienced difficulty in solving open problems in the form of diagrams. Therefore, it can be concluded that S-3 was able to solve problems but still experienced difficulty in making mathematical arguments and representing mathematical problems.

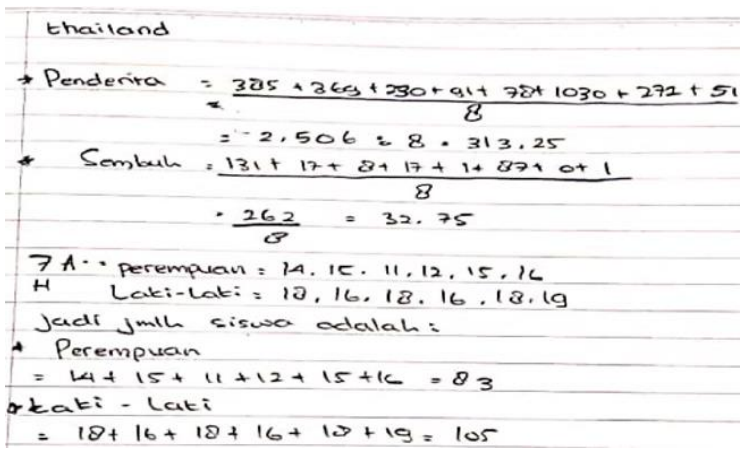

Figure 5 S-4 data

Based on Figure $5 \mathrm{~S}-4$ wrote down the answer to question number 1a by mentioning that the country with the lowest recovery rate was Thailand according to the diagram provided, but S-4 was less precise in describing the answers mentioned. To be more precise, S-4 should answer by showing a representation of the recovery rate. In question number $1 \mathrm{~b}, \mathrm{~S} 4$ answered the representation of ASEAN countries according to the picture without paying attention to the questions given. It seems that S-4 experienced difficulty in finding the correct answer to the question given even though he already had a reason for the answer. In question number 2, S-4 wrote down the number of male and female students correctly. Therefore, the researchers concluded that $\mathrm{S}-4$ was able to solve the given problem but still experienced difficulty in performing mathematical thinking to find the correct answer according to the given question.

In the aspect of mathematical thinking and argumentation, men and women can filter information and questions [18]. However, men usually see the problem and solve it most simply [19]. It is due to cognitive ability and speed in processing information 
[19]. Male students with low mathematical ability do not understand the problem well, so they find it difficult to determine the steps to solve the problem. Male students with low mathematical abilities often misinterpreted the problems given so that it is necessary to demonstrate literacy problems that contain aspects of communication as an exercise to improve communication skills [20]. Students with low mathematical abilities need to do exercises and learning to help students represent questions in the form of pictures and diagrams to facilitate problemsolving [20]. Female students in this category are only able to work on questions that contain aspects of mathematical thinking, mathematical models, open problems, and problem-solving, while mathematical arguments and mathematical representations have not been done well [18]. Formal, technical, and operational language as well as the use of mathematical tools have not been done well. Students could not communicate the purpose of the problem and design the appropriate strategies to solve problems so that students' ability to reason is also unsatisfactory. On the other hand, male students in the same category of mathematical self-concept have better mathematical literacy skills [16] that are by being able to master five aspects but have not been able to communicate problems well. It can be seen from students' problems in understanding and selecting the information needed to solve problems [16]-[18]. The results of interviews conducted by asking questions directly to the subject are almost the same that students do not understand the questions given so that they only wrote down what they think.

\section{CONCLUSION}

Based on the results and discussion, the researchers conclude that male subjects can implement mathematical literacy skills on indicators of mathematical models, open problems, and problemsolving, but have difficulties in understanding the descriptions on the diagrams given and interpreting open problems in diagram form. On the other hand, female subjects can implement mathematical literacy skills on mathematical model indicators, open problems and problem-solving, mathematical communication, but have problems in making mathematical arguments, representing mathematical problems, and mathematical thinking, namely being able to find answers according to questions correctly.

\section{ACKNOWLEDGMENTS}

The researchers would like to thank the Class VII students of SMP Negeri 20 Surakarta and the lecturer of the Catholic University Widya Mandira Kupang who have validated the instrument.

\section{REFERENCES}

[1] Fakhriyana, D., Mardiyana, \& Aryuna, D. R. (2018). Analisis Kemampuan Literasi Matematika dalam Memecahkan Masalah Model Programme For International Student Assessment (PISA) pada Konten Perubahan dan Hubungan Ditinjau dari Kecerdasan Logis Matematis Siswa Kelas IX SMP Muhammadiyah Program Khusus Surakart. Jurnal Pendidikan Matematika Dan Matematika (JPMM) Solusi, 2(6), 421-434.

[2] Febriyana, D., \& Suyitno, H. (2018). Analysis of Mathematical literacy Ability Viewed From Students' Mathematics Self-concept Based on Gender Differences on IMPROVE Learning with PMRI Approach. Unnes Journal of Mathematics Education Research, 7(2), 182188.

[3] Gnambs, T. (2021). The development of gender differences in information and communication technology (ICT) literacy in middle adolescence. Computers in Human Behavior, 114(August 2020), 106533. https://doi.org/10.1016/j.chb.2020.106533

[4] Hasnawati. (2016). Description of Mathematics Literacy Ability of Students First Secondary School State 15 Kendari Based on Content, Context, Materials, and Process. International Journal of Education and Research, 4(11), 2016. www.ijern.com

[5] Hera, R., \& Sari, N. (2015). Seminar Nasional Matematika dan Pendidikan Matematika Uny 2015713 Literasi Matematika: Apa, Mengapa dan Bagaimana? 713-720.

[6] Im, S. H., \& Jitendra, A. K. (2020). Analysis of proportional reasoning and misconceptions among students with mathematical learning disabilities. Journal of Mathematical Behavior, 57(August 2019), 100753. https://doi.org/10.1016/j.jmathb.2019.100753

[7] Kaum, L., Kaum, L., \& Datar, K. T. (2020). Article, Page 68 - 80. 3(1), 68-80.

[8] Kholid, M. N., Telasih, S., Pradana, L. N., \& Maharani, S. (2021). Reflective Thinking of Mathematics Prospective Teachers' for Problem Solving. Journal of Physics: Conference Series, 1783(1). https://doi.org/10.1088/17426596/1783/1/012102

[9] Lailiyah, S. (2017). Mathematical literacy skills 
of students' in term of gender differences. AIP Conference Proceedings, 1868(August 2017). https://doi.org/10.1063/1.4995146

[10] Mena, A. B. (2016). Literasi Matematis Siswa SMP dalam Menyelesaikan Masalah Kontekstual Ditinjau dari Adversity Quotient (AQ). Kreano, Jurnal Matematika KreatifInovatif, $\quad 7(2), \quad$ 187-198. https://doi.org/10.15294/kreano.v7i2.6756

[11] Mukuka, A., Mutarutinya, V., \& Balimuttajjo, S. (2020). Data on students' mathematical reasoning test scores: A quasi-experiment. Data in Brief, 30. https://doi.org/10.1016/j.dib.2020.105546

[12] Mullis, I. V. S., Martin, M. O., Foy, P., \& Arora, A. (2012). TIMSS 2011 International Results in Mathematics. In TIMSS \& PIRLS International Study Center (Vol. 2012, Issue 136). http://www.pubmedcentral.nih.gov/articlerende r.fcgi?artid=3295935\&tool=pmcentrez\&rendert ype $=$ abstract

[13] OECD. (2000). The PISA 2000 Assessment of Reading, Mathematical and Scientific Literacy. Oecd, 108.

[14] Pakpahan, R. (2017). Faktor-Faktor Yang Memengaruhi Capaian Literasi Matematika Siswa Indonesia Dalam Pisa 2012. Jurnal Pendidikan Dan Kebudayaan, 1(3), 331. https://doi.org/10.24832/jpnk.v1i3.496

[15] Prabawati, M., Herman, T., \& Turmudi. (2019). Mathematical literacy skills students of the junior high school in term of gender differences. Journal of Physics: Conference Series, 1315(1). https://doi.org/10.1088/17426596/1315/1/012084

[16] Rahmawati, E. (n.d.). Jurnal Pendidikan Matematika ( Eka Rahmawati ) | 1 Jurnal Pendidikan Matematika (Eka Rahmawati)| 2. $1-5$.

[17] Rambe, A. Y. F., \& Afri, D. L. (2020). Analisis Kemampuan Pemecahan Masalah Matematis Siswa dalam Menyelesaikan Soal Materi Barisan dan Deret. AXIOM : Jurnal Pendidikan Dan Matematika, 09(2), 175-187.

[18] Rimbatmojo, S., Kusmayadi, T. A., \& Riyadi, R. (2017). Profile of Visual-Spatial Intelligence In Solving Geometric of 11th Grades Viewed From Gender Differences. International Journal of Science and Applied Science: Conference Series, 2(1), 346. https://doi.org/10.20961/ijsascs.v2i1.16742

[19] Sa'dijah, C., Kholid, M. N., Hidayanto, E., \&
Permadi, H. (2021). Are there Differences in Reflective Thinking Between Male and Female Prospective Mathematics Teachers? Proceedings of the 7th International Conference on Research, Implementation, and Education of Mathematics and Sciences (ICRIEMS 2020), 528(Icriems 2020), 344-351. https://doi.org/10.2991/assehr.k.210305.050

[20] Zaman, A., Jumani, N. B., Ali, A., \& Hussain, M. A. (2011). Predictive validity of scores in mathematics for reasoning ability in mathematics for grade 9 students in Khyber Pakhtunkhwa based on curriculum of mathematics. Procedia - Social and Behavioral Sciences, $\quad$ 12, 588-594. https://doi.org/10.1016/j.sbspro.2011.02.072 